\title{
Determinants of Health Care Renunciation among Women in Ivory Coast: Case of the District of Abobo Anonkoi-3
}

\author{
Jérôme Kouame1,2), Julie-Ghislaine Sackou-Kouakou',2), Marie-Laure Tiade',3), \\ Régine Attia-Konan ${ }^{1,2)}$, Madikiny Coulibaly'), Aïssata Dagnogo(1), Kouame Koffi'i), \\ Annita Hounsa'), Mariette Gokpeya' ${ }^{1,3)}$, Simone Malik'), Angèle Desquith'), \\ Agbaya Oga',4), Kouakou Luc'1), Kouadio',3) \\ 1)Faculty of Pharmaceutical and Biological Sciences, Department of Public Health, \\ Hydrology and Toxicology, University Félix Houphouët Boigny, Abidjan, Ivory Coast \\ 2)Center for Research and Studies in Populations, Policies and Health Systems, \\ National Institute of Public Health, Abidjan, Ivory Coast \\ 3)Hygiene Laboratory, National Institute of Public Hygiene and health, Abidjan, Ivory Coast \\ 4) Medical Information department, Institute of Cardiology, Abidjan, Ivory Coast
}

\section{ABSTRACT}

Background: Health care renunciation aims to identify unmet care needs that a health condition would have justified. This behavior appears to be more common in women than in men. The objective of this work was to analyze the determinants of the health care renunciation among women in the city of Abidjan.

Subjects and Method: We carried out a cross-sectional study from March to May 2019 in Anonkoi-3, a peri-urban district of the municipality of Abobo, in the north of the city of Abidjan. Questionnaires served to collect informations. Bivariate analyzes and a multiple logistic regression were used to measure the association between the different types of renunciation and the characteristics of women. Dependant variable was healthcare renunciation. Independent variables were socio-demographic, economic, health status characteristics and reasons for renouncing to health care.

Results: The population sample consisted of 423 women (with mean age $=32 ; \mathrm{SD}=12$ years). The renunciation on consultations with the general practitioner concerned, $72.34 \%$ of women. Regarding consultation with the specialist, the ophthalmologist (25.05\%), the dentist (21.99\%), and the gynecologist (14.89\%) were those mostly renounced by the women. After consultation, $31.2 \%$ of them renounced to pursuing other treatment. They most often renounced to buying drugs from conventional medicine (19.62\%) and preferred to use street drugs and traditional drugs (87.71\%). All things being equal, women aged 28 to $38(\mathrm{OR}=2.45$; $95 \% \mathrm{CI}=1.31$ to $4.68 ; \mathrm{p}=0.013)$, artisans and traders $(\mathrm{OR}=3.22 ; 95 \% \mathrm{CI}=1.48$ to $7.38 ; \mathrm{p}=$ $0.004)$ and those in trade learning $(\mathrm{OR}=2.42$; $95 \% \mathrm{CI}=1.12$ to $5.49 ; \mathrm{p}=0.028$ ) significantly renouncing more on health care.

Conclusion: In addition to financial reasons, the renunciation on health care can be explained by individual and social behaviors specific to individuals.

Keywords: women, healthcare renunciation, precariousness, social inequalities, ivory coast

\section{Correspondence:}

Jérôme Kouame, Faculty of Pharmaceutical and Biological Sciences, Department of Public Health, Hydrology and Toxicology, University Félix Houphouët Boigny, BPV 34 Abidjan 01, Ivory Coast. Email: jerome.kouamejj@gmail.com. Mobile: 0022565237900.

\section{Cite this as:}

Kouame J, Sackou-Kouakou JG, Tiade ML, Attia-Konan R, Coulibaly M, Dagnogo A, Koffi K, Hounsa A, Gokpeya M, Malik S, Desquith A, Oga A, Luc K, Kouadio (2021). Determinants of Health Care Renunciation among Women in Ivory Coast: Case of the District of Abobo Anonkoi-3. J Health Policy Manage. 06(02): 116129. https://doi.org/10.26911/thejhpm.2021.06.02.04. 


\section{BACKGROUND}

The renunciation to health care reflects the fact that people feel the need to seek for medical attention, and ultimately giving up on it for various reasons (Després et al., 2011a; Desprès, 2013; Warin et al., 2015). The need for treatment can be diagnosed by a medical practitioner or identified by the patient himself (Chaupain-Guillot, Guillot and Jankeliowitch-Laval, 2014). The fact that treatment are being renounced would contribute to the deteriorating state of health. The treatment, management of people who have renounced to treatment can extend over relatively long periods and incur significant costs (Allonier, Dourgnon and Rochereau, 2010; Dourgnon, Jusot and Fantin, 2012).

The treatment renunciation has been described in several developed countries, despite universal health coverage and specific assistance to the most vulnerable people in these countries. In the United States, Tuckett in 1978 had shown that part of the population considered sick by conventional medicine did not consult a doctor, even in a context of free health care services (Tuckett, 2013). In France, the renunciation was more marked for dental and optical care services (Després et al., 2011b; ChaupainGuillot, Guillot and Jankeliowitch-Laval, 2014; Revil, Casagran and Chauveaud, 2016). In sub-Saharan Africa, the frequencies of renunciation to treatment are not well known.

Renunciation to treatment can thus occur at different stages of the health care pathway. Classically, populations renounce to entering (at the time of medical consultations) or continue in the conventional health care system (Després et al., 2011b; Wolff, Gaspoz and Guessous, 2011). This phenomenon is the result of both dysfunctions in the organization of the health care system and of personal and cultural factors specific to the individuals (Chauvin et al., 2011).

Although the literature reported mainly renunciation due to financial reasons (Després et al., 2011b; Wolff, Gaspoz and Guessous, 2011; Guessous et al., 2014), studies have underlined the diversity of explanatory factors. These factors are linked to the health status and living conditions of the populations (Allin, Grignon and Le Grand, 2010; Jusot, 2013; Bouba-Olga, Vigé and Vigé, 2014; Warin et al., 2015; Ancelot, Bonnal and Depret, 2016; Revil, Casagran and Chauveaud, 2016; Baggio, Iglesias and Fernex, 2017; Revil, 2017). Higher frequencies of renunciation have been found in people living under precarious situations (Després et al., 2011b; Jusot, 2013; Ancelot, Bonnal and Depret, 2016), those who had a low level of education (Bouba-Olga, Vigé and Vigé, 2014) and those who were not covered or poorly covered by the supplementary health insurance coverage (Després et al., 2011b). In addition to these factors mentioned above, women seem to have a greater probability of renouncing to treatment than men (Revil, Casagran and Chauveaud, 2016; Revil, 2017). A greater risk of renouncing to health care in women was first found by Chauvin in 2011 (Chauvin et al., 2011) before being confirmed, in 2016, by the French observatory of non-use of rights and services (Revil, Casagran and Chauveaud, 2016).

As the World Health Organization (WHO) reminded us, women, despite a higher life expectancy, continue to have a poorer quality of life. They perceive themselves to be in poor health more often and report more illnesses (World Health Organisation, 2009). This poor health can be attributed to their low purchasing power. Indeed, poverty strikes women more than men. Among the 1.5 billion people who live 
on $\$ 1$ a day or less, there are predominantly women (United Nations, 2000). A third of households in the world are headed by women; 80 to $90 \%$ of poor families are headed by a woman (Centre International de solidarité ouvrière, 2002; Agence Belge de developpement, 2012) (Centre International de solidarité ouvrière, 2002; Agence Belge de developpement, 2012).

In Côte d'Ivoire, women represent close to half (48.3\%) of the population (Institut National de la statistique de Côte d'Ivoire, 2015). Few studies have addressed the issue of renunciation to health care. This study aimed to analyze the determinants of renouncing to treatment at different stages of the health care pathway for women in Abidjan.

\section{SUBJECTS AND METHOD}

\section{Study Design}

A cross-sectional study, with a descriptive and analytical focus, was conducted from March to May 2019, in Anonkoi-3, a periurban neighborhood in the municipal of Abobo, northern zone of the city of Abidjan. We estimated the frequencies of care renunciation among women and analyzed the associations between care renunciation and socio-demographic, economic and health-related characteristics of women.

\section{Population and Sample}

At the last general population and housing census in 2014, the population of Abobo was estimated to be about 1,030,658 inhabitants, of which $49.26 \%$ were women; Anonkoi-3 district had about 4,814 inhabitants and 754 households (Institut National de la statistique de Côte d'Ivoire, 2015). This neighborhood falls to the Abobo-West health district. Health centers are available there within less than five (5) kilometers to homes (Ministère de la santé et de l'hygiène publique République de Côte d'Ivoire, 2018).
The target population consisted of women aged at least 18 years, residing in Anonkoi-3. The source population was identical to the target population. Women aged 18 years and older, living for at least three (3) months in the neighborhood and present at the time of the survey were included in the study. Not included were those absent after two (2) confirmed appointments.

The selection of women was made by a random survey. Households in the neighborhood were not numbered. Using a map, we divided the neighborhood, at random, into thirty (30) zones. In each area, we chose fourteen (14) households, except in three areas where we chose fifteen (15) in order to be consistent with the sample size we had estimated. In each zone, the first household was drawn and one in two households was visited. In each household we interviewed only one woman. Community health workers served as a guide to facilitate access to households.

The sample size was determined using Schwartz's formula (Schwartz, 1995). Due to the lack of previous study estimating the rate of renunciation to health care in Côte d'Ivoire, we have chosen to put it at $50 \%$. The number of women to be included in the study after calculation was 384 . Assuming a non-response rate of $10 \%$, we finally included 423 women in the study.

\section{Study Variables}

The dependant variable was renunciation to health care in the last twelve months preceding the survey. The independent variables were:

Socio-demographic characteristics: age, marital status, level of education, occupation, number of dependents, housing status, participation in community life.

Economic characteristics and those of the state of health of women: The benefit of a remunerated activity, monthly 
income, general state of health and the perception of its evolution since the previous year, the attendance of health care facilities accessible free of charge, the benefit of health insurance cover, the reasons for the absence of health insurance cover (if applicable).

The reasons for renouncing to health care.

\section{Operational Definition of Variables} Renunciation to health care in the last twelve months preceding the survey: It referred to care needs that were unmet by choice, coercion, or due to insufficient or inadequate care or treatment being received. It was collected using the following two questions: "In the past twelve months have you renounced to a medical consultation? "And" In the past twelve months have you given up on treatment after seeing a doctor?". The type of treatment renounced was then recorded. We considered that a woman had renounced to treatment if she had either renounced medical consultations only, or renounced compulsory or advised medical procedures only, or renounced both. The measurement scale was dichotomus, coded $\mathrm{O}=$ "no" and $1=$ "yes".

\section{Socio-demographic characteristics:}

Age was the number of years since the woman was born and until the time of data collection. The age variable was then categorized according to quartiles.

Marital status was the fact of women living in couple (with a jobless spouse or not) or being single. It was a categorical variable with the following modalities: single, couple (spouse active) and couple (spouse inactive). Secondly, marital status was considered as a dichotomous variable, coded $\mathrm{o}=$ "single" and $1=$ "couple".

Level of education was the highest level of formal education ever completed. It was a categorical variable with the following modalities: not educated, primary school, secondary school and higher education.

Occupation was the main professional activity of women. They were asked to fill it in on the survey form. The occupation was then classified as: learner, jobless, artisan/ trader, executive/employee and pensioner.

Number of dependants referred to the number of people who were living with and physically and financially dependent on the women at the time of the survey. They were asked to fill it in on the survey form. The number of dependants was then categorized as: o, 1 to 2, 3 to 4 and more than 4 .

Housing status defined the legal situation of household regarding the occupation of its main residence. There were three main statuses:

- The status of tenant was applied to women paying rent regardless of the type of dwelling they occupy;

- The status of lodger (tiers/family) was applied to women who do not owned their dwelling and do not paid rent;

- The owner status referred to women who owned their households.

Participation in community life referred to the fact that women take part, on a regular or irregular basis, in the activities of a group of people for whatever purpose. They were asked to specify the nature of the community activity in which they participated. The community activities was then classified as: religious, communal, tontine, volunteering or non-community life. Secondly, participation in community life was considered as a dichotomous variable, coded $\mathrm{o}=$ "no" and $1=$ "yes".

Economic characteristics and those of the state of health of women:

Paid activities were activities for remuneration for certain services, such as employment by another person or organization. It was considered as a dichotomous variable, coded $\mathrm{o}=$ "no" and $1=$ "yes". 
Monthly income was the fixed income in West African CFA franc (XOF currency) received each month by women. It was a categorized in four classes: None, 1 to $30,000 \mathrm{XOF}, 30,001$ to $60,000 \mathrm{XOF}$, and more than 60,000 XOF.

General health status was the general state of health as perceived by women. It was a categorical variable with the modalities: bad, good and excellent.

Perception of the evolution of general state of health since the previous year. It was a categorical variable with the modalities: worse, identical and better.

Attendance of health care facilities accessible free of charge it was considered as a dichotomous variable, coded $\mathrm{o}=$ "no" and $1=$ "yes".

Health insurance coverage it was considered as a dichotomous variable, coded o= "no" and $1=$ "yes".

Reasons for the absence of health insurance cover (if applicable) women were asked to fill it in on the survey form.

The reasons for renouncing to health women were asked to provide information on the reasons for giving up care. These reasons were then grouped into categories, according to whether they were financial, related to the organization of care, health personnel or purely personal reasons.

\section{Study Instruments}

A pre-tested questionnaire was used to collect all data of this study.

\section{Data Analysis}

Data were entered by EPIDATA 3.1 software and analyzed using Rstudio 1.1.447 software. Each variable was subjected to descriptive analysis. The frequencies of renunciation to consultation (with a general practitioner and a specialist) and those of renouncing after consultation were estimated, along with their confidence intervals.
The search for factors associated with renunciation to health care was carried out in two steps. First, the associations between renunciation to health care (at the consultation and after consultation) and other variables were explored using the $\chi^{2}$ test (or, where appropriate, Fisher's exact test) in bivariate analyzes. The threshold of statistical significance was set at $5 \%$.

Three logistic regression models were constructed. They included, in each one, all the variables that had a p-value of less than $20 \%$ in bivariate analyzes. Using the topdown step-by-step selection procedure, the variables that provided the least information to the models were phased out until final models were obtained that consisted only of significant variables ( $\mathrm{p}$-values $<5 \%$ ).

\section{Research Ethic}

To carry out this study, we obtained the authorizations from the Director of training and research of the Ministry of Public Health and Hygiene, that of the District Director of Health of Abobo-Ouest and that of the leaders of the neighborhood (neighborhood leaders and community leaders). The written consent of the participants was obtained. Data collection, entry and analysis was anonymous.

\section{RESULTS}

\section{Sample Characteristics}

The sample consisted of 423 women (mean age $=32, \mathrm{SD}=12$ years old). Most of these women were in a relationship with a partner who was professionally active (53.20\%). Most of them had a secondary school level of national education (36.17\%), and were still learning a trade at the time of the survey (35.70\%). More than half of them had no dependents (54.85\%) and were tenant of their house (56.97\%). About 4 out of 10 women had a paid job, $14.42 \%$ of them received a monthly income above the guaranteed minimum inter-professional 
Kouame et al./ Determinants of Health Care Renunciation among Women

wage (SMIG) in Ivory Coast which is 60,000 XOF (90 Euros).

Table 1. Sociodemographic, economic and health status of women

\begin{tabular}{|c|c|c|c|}
\hline \multirow{2}{*}{\multicolumn{4}{|c|}{$\begin{array}{l}\text { Characteristics Category } \\
\text { Demographic characteristics }\end{array}$}} \\
\hline & & & \\
\hline \multirow[t]{4}{*}{ Age } & $-<23$ & 92 & $21.75 \%$ \\
\hline & $-23-27$ & 111 & $26.24 \%$ \\
\hline & $-28-38$ & 112 & $26.48 \%$ \\
\hline & $-\geq 39$ & 108 & $25.53 \%$ \\
\hline \multirow[t]{3}{*}{ Marital status } & - couple (spouse active) & 225 & $53.20 \%$ \\
\hline & - Single & 180 & $42.55 \%$ \\
\hline & - couple (spouse inactive) & 18 & $4.25 \%$ \\
\hline \multirow[t]{4}{*}{ Level of Education } & - not educated & 70 & $16.55 \%$ \\
\hline & - primary school & 74 & $17.49 \%$ \\
\hline & - secondary school & 153 & $36.17 \%$ \\
\hline & - higher education & 126 & $29.79 \%$ \\
\hline \multirow[t]{5}{*}{ Occupation } & - learner & 151 & $35.70 \%$ \\
\hline & - jobless & 96 & $22.70 \%$ \\
\hline & - artisan/trader & 132 & $31.20 \%$ \\
\hline & - executive/employee & 34 & $8.04 \%$ \\
\hline & - pensioner & 10 & $2.36 \%$ \\
\hline \multirow[t]{4}{*}{ Number of dependents } & -0 & 232 & $54.85 \%$ \\
\hline & -1 to 2 & 124 & $29.31 \%$ \\
\hline & -3 to 4 & 49 & $11.58 \%$ \\
\hline & $->4$ & 18 & $4.26 \%$ \\
\hline \multirow[t]{3}{*}{ Housing status } & - tenant & 241 & $56.97 \%$ \\
\hline & -lodger(Tiers/Family) & 164 & $38.77 \%$ \\
\hline & - house owner & 18 & $4.26 \%$ \\
\hline \multirow[t]{5}{*}{ Community life } & - None & 153 & $36.17 \%$ \\
\hline & - religious & 134 & $31.68 \%$ \\
\hline & - communal & 65 & $15.36 \%$ \\
\hline & - tontine & 53 & $12.53 \%$ \\
\hline & - volunteering & 18 & $4.26 \%$ \\
\hline \multicolumn{4}{|c|}{ Economic characteristics and health status of women } \\
\hline \multirow[t]{2}{*}{ Paid activity } & - Yes & 166 & $39.24 \%$ \\
\hline & - No & 257 & $60.76 \%$ \\
\hline \multirow{4}{*}{$\begin{array}{l}\text { Monthly income (in XOF } \\
\text { currency) }\end{array}$} & - None & 257 & $60.76 \%$ \\
\hline & $-1-30000$ & 29 & $6.85 \%$ \\
\hline & $-30001-60000$ & 76 & $17.97 \%$ \\
\hline & $->60000$ & 61 & $14.42 \%$ \\
\hline \multirow{3}{*}{ General health status } & - bad & 14 & $3.31 \%$ \\
\hline & - good & 372 & $87.94 \%$ \\
\hline & - excellent & 37 & $8.75 \%$ \\
\hline \multicolumn{4}{|c|}{ Perception of the evolution of the state of health in one year } \\
\hline & - worse & 58 & $13.71 \%$ \\
\hline & - identical & 140 & $33.10 \%$ \\
\hline \multirow{2}{*}{\multicolumn{4}{|c|}{$\begin{array}{c}\text { - better } \\
\text { Access to health centres with free health services }\end{array}$}} \\
\hline & & & \\
\hline & - yes & 16 & $3.78 \%$ \\
\hline \multirow{2}{*}{\multicolumn{4}{|c|}{ Health insurance coverage ${ }^{- \text {no }}$}} \\
\hline & & & \\
\hline & - yes & 128 & $30.26 \%$ \\
\hline & & 295 & $69.74 \%$ \\
\hline \multicolumn{4}{|c|}{ Reasons for the lack of health insurance coverage $(N=295)$} \\
\hline & - lack of information & 148 & $50.17 \%$ \\
\hline & - lack of funds & 100 & $33.90 \%$ \\
\hline & - other priorities & 37 & $12.54 \%$ \\
\hline & - not felt needs & 10 & $3.39 \%$ \\
\hline
\end{tabular}


Most of the women were involved in association activities (63.83\%). They mainly participated in religious activities (31.68\%). More than two-thirds of the women did not have any health insurance coverage (69.74\%). The main reason (50.17\%) was lack of information.
Almost nine in 10 women (87.94\%) perceived their state of health to be good. Just over half of them (53.19\%) did not notice any change in their health over the past year. The socio-demographic, economic and health status characteristics of women were presented in Table 1.

Table 2. Characteristics and reasons for renouncing to health care

\begin{tabular}{|c|c|c|c|c|}
\hline \multirow{2}{*}{ Renouncement to health care } & \multirow{2}{*}{$\mathbf{N}$} & \multirow{2}{*}{ (\%) } & \multicolumn{2}{|c|}{ CI (95\%) } \\
\hline & & & Lower Limit & Upper Limit \\
\hline \multicolumn{5}{|l|}{ Renunciation of consultation } \\
\hline At the general practitioner & 306 & 72.34 & 67.77 & 76.50 \\
\hline \multicolumn{5}{|l|}{ At the specialist } \\
\hline All specialties combined & 226 & 53.43 & 48.55 & 58.25 \\
\hline Ophthalmologist & 106 & 25.05 & 21.06 & 29.52 \\
\hline Dentist & 93 & 21.99 & 18.20 & 26.30 \\
\hline Gynecologist (except pregnancy) & 63 & 14.89 & 12.00 & 19.00 \\
\hline Dermatologist & 4 & 0.94 & 0.30 & 2.57 \\
\hline Cardiologist & 2 & 0.47 & 0.08 & 1.89 \\
\hline Psychiatrist & 1 & 0.24 & 0.01 & 1.52 \\
\hline \multicolumn{5}{|l|}{ Renouncement of post-consultation care } \\
\hline \multicolumn{5}{|l|}{ Therapy } \\
\hline All treatments combined & 132 & 31.20 & 26.86 & $35 \cdot 90$ \\
\hline Pharmaceuticals & 83 & 19.62 & 16.01 & 23.80 \\
\hline Optical & 26 & 6.15 & 4.13 & 8.99 \\
\hline Dental care & 21 & 4.96 & 3.18 & 7.61 \\
\hline Surgery & 11 & 2.60 & 1.37 & 4.74 \\
\hline Physiotherapy & 2 & 0.47 & 0.08 & 1.89 \\
\hline \multicolumn{5}{|l|}{ Paraclinical examinations } \\
\hline All laboratory tests combined & 42 & 9.92 & $7 \cdot 33$ & 13.28 \\
\hline Biological & 39 & 9.22 & 6.72 & 12.49 \\
\hline Imaging & 7 & 1.65 & 0.73 & 3.53 \\
\hline \multicolumn{5}{|l|}{ Reasons for renouncement to health care } \\
\hline \multicolumn{5}{|l|}{ Personal Reason } \\
\hline All reasons combined & 418 & 98.82 & 97.10 & $99 \cdot 56$ \\
\hline Practice of unconventional care $*$ & 371 & 87.71 & 84.10 & 90.61 \\
\hline Personal choice not to seek for care & 163 & 38.53 & 33.90 & $43 \cdot 38$ \\
\hline Fear of hospital care and diagnosis & 41 & 9.70 & 7.12 & 13.02 \\
\hline \multicolumn{5}{|l|}{ Financial Reasons } \\
\hline All reasons combined & 250 & 59.10 & 54.24 & 63.80 \\
\hline Lack of health insurance coverage & 179 & 42.32 & 37.58 & 47.20 \\
\hline Lack of financial means & 62 & 14.66 & 11.50 & 18.47 \\
\hline High cost of transport & 11 & 2.60 & 1.37 & 4.74 \\
\hline Care not covered by the insurance & 3 & 0.71 & 0.18 & 2.24 \\
\hline \multicolumn{5}{|l|}{ Reasons related to health workers } \\
\hline All reasons combined & 201 & $47 \cdot 52$ & 42.69 & 52.40 \\
\hline Overproduction of care & 134 & 31.68 & $27 \cdot 31$ & 36.38 \\
\hline Difficult relationships with health workers & 88 & 20.80 & 17.10 & 25.05 \\
\hline \multicolumn{5}{|l|}{ Reasons related to the health care organization } \\
\hline All reasons combined & 233 & 55.08 & 50.20 & 59.87 \\
\hline Unsuitable hours & 187 & 44.21 & 39.43 & 49.10 \\
\hline Too long appointment deadlines & 79 & 18.68 & 15.14 & 22.80 \\
\hline Poor quality of material & 3 & 0.71 & 0.18 & 2.24 \\
\hline
\end{tabular}

*Traditional medicines and street drugs 


\section{Renunciation to health care during the last twelve months.}

Table 2 described the characteristics and reasons for renouncing to treatment. Almost all the women (99.80\%) had, at least once, renounce to go for a consultation in the last twelve months. The proportion of women who renounced to a consultation with a general practitioner was $72.34 \%$. Regarding consultation with a specialist, the ophthalmologist (25.05\%), the dentist (21.99\%), and the gynecologist (14.89\%) were those that women renounced the most. Renunciation at the post-consultation was observed in $31.20 \%$ of women. They most often renounced to buying drugs (19.62\%).

Women were more likely to renounce to treatment for personal reasons (98.82\%). They preferred to use other therapies (87.71\%). The second reason for renunciation to treatment was financial $(59.10 \%)$, mainly the lack of health risk insurance coverage. The other reasons were related to the organization of the health care service (55.08\%) and health staff (47.52\%).

\section{The result of bivariate analysis}

Table 3 presented the results of the bivariate analyzes of the factors associated with renouncement to health care. A statistically significant association was shown between age (28-38 years old) and the renouncement to consultations with the general practitioner $(\mathrm{OR}=2.25 ; 95 \% \mathrm{CI}=$ 1.31 to $4.68 ; \mathrm{p}=0.028$ ).

Renunciation to consultations (with the general practitioner and/or specialist) was not significantly associated with any of the variables describing the economic characteristics and health status of women. The other socio-demographic characteristics (marital status, level of education, number of dependents, housing occupancy status) did not influence the renunciation to consultations.

The associations between renouncement to consultations and the different categories of reasons mentioned by the women interviewed did not show significant differences.

As for renouncement after consultation, it was associated with single marital status $(\mathrm{OR}=1.70 ; 95 \% \mathrm{CI}=1.12$ to $2.58 ; \mathrm{p}=$ o.016), having no income $(\mathrm{OR}=3.33$; $95 \%$ $\mathrm{CI}=1.60$ to $7.86 ; \mathrm{p}=0.006)$ and lack of health insurance coverage $(\mathrm{OR}=2.67 ; 95 \%$ $\mathrm{CI}=1.63$ to $4.54 ; \mathrm{p}<0.001)$.

\section{The result of multilevel analysis}

Table 4 presented the results of the multivariate analyzes of the factors associated with renouncement to health care. After adjusting for the covariates, compared to older women, those in the 28-38 age group significantly, renounced twice as often, to consultations with the general practitioner $(\mathrm{OR}=2.45 ; 95 \% \mathrm{CI}=1.31$ to $4.68 ; \mathrm{p}=$ 0.013).

Women working as artisans and traders significantly renounced consultations with specialists $(\mathrm{OR}=3.22 ; 95 \% \mathrm{CI}=$ 1.48 to $7.38 ; \mathrm{p}=0.004)$. Those who were learning a trade renounced consultations twice as often $(\mathrm{OR}=2.42 ; 95 \% \mathrm{CI}=1.12$ to $5.49 ; \mathrm{p}=0.028$ ), compared to executives and employees.

Regardless of the other factors included in the model, single women (OR= 1.71; $95 \% \mathrm{CI}=1.06$ to $2.80 ; \mathrm{p}=0.028$ ) and those with an income between 30001 and $60,000 \mathrm{XOF}(\mathrm{OR}=3.16 ; 95 \% \mathrm{CI}=1.33$ to $8.20 ; \mathrm{p}=0.012)$ renounced much more to health care after consultation. They mainly mentioned financial reasons $(\mathrm{OR}=2.34$; $95 \% \mathrm{CI}=1.47$ to $3.80 ; \mathrm{p}=0.001$ ). 
Kouame et al./ Determinants of Health Care Renunciation among Women

Table 3. Bivariate analysis of the factors associated with renouncement to consultation

\begin{tabular}{|c|c|c|c|c|c|c|}
\hline \multirow{3}{*}{ Variables } & \multicolumn{6}{|c|}{$\begin{array}{l}\text { Renouncement to consultation } \\
\end{array}$} \\
\hline & \multicolumn{2}{|c|}{ Generalist } & \multicolumn{2}{|c|}{ Specialist } & \multirow{2}{*}{$\mathbf{O R}$} & \multirow{2}{*}{$\mathbf{p}$} \\
\hline & $\mathbf{N}$ & $\%$ & $\mathbf{N}$ & $\%$ & & \\
\hline \multicolumn{7}{|l|}{ Age (Years) } \\
\hline$-<28$ & 139 & 68.5 & 109 & 53.7 & & \\
\hline$-\geq 28$ & 167 & 75.9 & 117 & 53.2 & 1.45 & 0.088 \\
\hline \multicolumn{7}{|l|}{ Marital status } \\
\hline - married & 178 & $73 \cdot 3$ & 123 & 50.6 & & \\
\hline - unmarried & 128 & 71.1 & 103 & 57.2 & 1.31 & 0.016 \\
\hline \multicolumn{7}{|l|}{ Level of education } \\
\hline - not educated & 53 & 75.7 & 41 & 58.6 & & \\
\hline - educated & 253 & 71.7 & 185 & 52.4 & 0.78 & 0.346 \\
\hline \multicolumn{7}{|l|}{ Occupation } \\
\hline - with a job & 221 & 69.7 & 172 & $54 \cdot 3$ & & \\
\hline - jobless & 85 & 80.2 & 54 & 50.9 & 2.61 & 0.146 \\
\hline \multicolumn{7}{|l|}{ Number of dependents } \\
\hline - none & 140 & $73 \cdot 3$ & 102 & 53.4 & & \\
\hline$-\geq 1$ & 166 & 71.6 & 124 & $53 \cdot 4$ & 1.00 & 0.993 \\
\hline \multicolumn{7}{|l|}{ Housing status } \\
\hline - tenant & 175 & 72.6 & 131 & 54.4 & & \\
\hline - house owner or lodger & 131 & 72.0 & 95 & 52.2 & 0.92 & 0.659 \\
\hline \multicolumn{7}{|l|}{ Paid activity } \\
\hline- no & 186 & 72.4 & 135 & 52.5 & & \\
\hline - yes & 120 & 72.3 & 91 & 54.8 & 1.10 & 0.645 \\
\hline \multicolumn{7}{|l|}{ Income } \\
\hline - yes & 120 & 72.3 & 91 & 54.8 & & \\
\hline- no & 186 & 72.4 & 135 & 52.5 & 3.33 & 0.06 \\
\hline \multicolumn{7}{|l|}{ Associative Life } \\
\hline - yes & 188 & 69.6 & 147 & 54.4 & & \\
\hline- no & 118 & 77.1 & 79 & 51.6 & 0.89 & 0.578 \\
\hline \multicolumn{7}{|c|}{ Health insurance coverage } \\
\hline - yes & 98 & 76.6 & 65 & 50.8 & & \\
\hline- no & 208 & 70.5 & 161 & 54.6 & 1.16 & 0.472 \\
\hline \multicolumn{7}{|l|}{ Perceived health } \\
\hline - good or excellent & 294 & 71.9 & 218 & $53 \cdot 3$ & & \\
\hline - bad & 12 & 85.7 & 8 & 57.1 & 1.17 & 0.777 \\
\hline \multicolumn{7}{|c|}{ Evolution of state of Health } \\
\hline - identical or better & 267 & 73.2 & 192 & 52.6 & & \\
\hline - worst & 39 & 67.2 & 34 & 58.6 & 1.28 & 0.394 \\
\hline \multicolumn{7}{|l|}{ Financial reason } \\
\hline - no & 127 & 73.4 & 91 & 52.6 & & \\
\hline - yes & 179 & 71.6 & 135 & 54.0 & 2.64 & $<0.001$ \\
\hline \multicolumn{7}{|c|}{ Reason related to health care organization } \\
\hline - no & 140 & 73.7 & 94 & 49.5 & & \\
\hline - yes & 166 & 71.2 & 132 & 56.7 & 1.33 & 0.141 \\
\hline Reasons related to per & alth & & & & & \\
\hline- no & 2 & 40.0 & 3 & 60.0 & & \\
\hline - yes & 304 & 72.7 & 223 & $53 \cdot 3$ & 0.76 & 0.768 \\
\hline Reasons related to hea & taff & & & & & \\
\hline- no & 159 & 71.6 & 111 & 50.0 & & \\
\hline - yes & 147 & 73.1 & 115 & 57.2 & 1.34 & 0.138 \\
\hline
\end{tabular}


Kouame et al./ Determinants of Health Care Renunciation among Women

Table 4. The result of multiple logistic regression analysis

\begin{tabular}{|c|c|c|c|c|}
\hline \multirow[b]{2}{*}{ Independent Variables } & \multirow{2}{*}{$\mathbf{O R}$} & \multicolumn{2}{|c|}{$95 \%$ CI } & \multirow[b]{2}{*}{$\mathbf{p}$} \\
\hline & & Lower limit & Upper limit & \\
\hline Age (Years) & 2.45 & 1.31 & 4.68 & 0.013 \\
\hline Occupation & 3.22 & 1.48 & $7 \cdot 38$ & 0.004 \\
\hline Marital status & 1.71 & 1.06 & 2.80 & 0.028 \\
\hline Income & 3.16 & 1.33 & 8.20 & 0.012 \\
\hline Financial reason & 2.34 & 1.47 & 3.80 & 0.001 \\
\hline N observation & 423 & & & \\
\hline Nagelkerke R² & 0.032 & & & \\
\hline Hosmer and Lemeshow & & & & \\
\hline goodness of fit test: $p=1.000$ & & & & \\
\hline
\end{tabular}

\section{DISCUSSION}

\section{Frequencies and reasons for treat-} ment renouncement

About three of four women had renounced to general practitioner consultation in the past 12 months. One of two women had given up to consultation with the specialist. These results may reflect the difficulties these women experienced to entering in the health care system. Regarding consultations with the specialist, the renouncement was more noticed with the ophthalmologist (25.05\%), the dentist (21.99\%), and the gynecologist except pregnancy (14.89\%). The order of priority in the renouncement to consultations with a specialist is different from that observed in France. In that country, the renouncement due to financial reasons concerned first dental care (38.6\%) and then eye care (20.4\%) (Revil, Casagran and Chauveaud, 2016). The renunciation to gynecological consultations outside pregnancy could be explained by the fact that reproductive health care (prenatal, postnatal and family planning consultations) was free or subsidized in Côte d'Ivoire. But women's health is not limited to reproductive problems. Cardiovascular disease and cancer (of the cervix, breast) are among the most common causes of death in women (World Health Organisation, 2018). In addition, altered oral health is frequently observed during and after pregnancy (Hart- nett et al., 2016). The results of our study may suggest that the usual management of pregnancy-related problems was partial since the dental care renouncement was high.

Renouncement to post-consultation care was more pronounced when purchasing drugs (19.62\%). The financial burden of paying for prescriptions appears to be the main difficulty women faced in maintaining themselves in the health care system. They thus preferred to use other types of medication $(87.71 \%)$, in this case street and traditional medicine. Angbo-Effi et al. (2011) in an urban study in Côte d'Ivoire noted that $72 \%(\mathrm{~N}=300)$ of respondents preferentially consumed drugs from the street, due to their low cost.

The high propensity of women to renounce to seeking for medical attention, combined with the propensity to renounce to purchasing drugs, poses problems of accessibility and acceptability of treatment; all the more so as only $3.78 \%$ of them attended free health care centers. In France, renouncement to the purchase of drugs was observed in only $6.6 \%(\mathrm{~N}=7542)$ of women (Revil, Casagran and Chauveaud, 2016).

Financial reasons, mainly the lack of health insurance coverage, were mentioned only in the background, after personal reasons. Renouncement was most often 
found after consultations. The renouncement rate for financial reasons $(59.10 \%)$ is far higher than that observed in Île de France by Bazin in 2001, which was $14.2 \%$ (Bazin, Parizot and Chauvin, 2006).

The availability of practitioners at any time of the day and as quickly as possible for appointments has been criticized. The same is true of the tendency of health professionals to administer far more care to women than they consider necessary for a given disease.

\section{Factors associated with renounce- ment with treatment}

Women aged 28 to 38 , working as artisans and/or traders were more likely to renounce entering the health care system. The age at which women renounce to treatment, remains controversial in the literature. Our results confirmed those of Dourgnon (Dourgnon, Jusot and Fantin, 2012), Desprès (2011) and Bazin (2006) who noted a higher probability of renouncement to health care in women under 40 years of age. Bazin explained this fact by the lower income that women in this age group earned, which did not allow them to have access to the needed medical care.

Single women, those who did not have health insurance coverage and those with an income between 30001 and 60,000 XOF (90 euros) were much more reluctant to stay in the health care system. In addition to the current burdens of community life, these women face sometimes very heavy burdens of taking charge of their health problems. Their insufficient financial resources could justify their renouncement to treatment.

The low level of education and the large number of dependents, which were nevertheless described in previous work as determinants in the renouncement of treatment (Bouba-Olga, Vigé and Vigé, 2014; Revil, Casagran and Chauveaud,
2016) did not find statistical significance in our study. Therefore, these facts seem not to affect the renouncement to care among women in the locality of Anonkoi-3.

\section{Limitations and conclusion}

One of the main fact limiting our study was the way in which renouncement to treatment is being measured. The data were collected on the basis of the statement made by the women surveyed. This can introduce a desirability bias. This bias was minimized by the presence of community health workers when the questionnaire was administered.

The study was also carried out in an urban environment, in a locality with a higher probability of finding only women from the lower and middle classes of Ivorian society. While the age structure of the women sampled is comparable to that of the female population in Côte d'Ivoire, the sample included a lower proportion of illiterate women than that of the general population. The results are therefore not generalizable to all women in Côte d'Ivoire.

This study highlighted the difficulties in accessing health care for women at different stages of their treatment care pathway. Determinants of renouncement to health care were women's age, occupation, marital status, income, and health insurance coverage. This renouncement to health care was therefore a combination of multiple reasons, far from being solely financial. Sociological analyzes would allow a better appreciation of other influencing factors.

\section{AUTHOR CONTRIBUTION}

Jérôme Kouame, Julie-Ghislaine SackouKouakou and Marie-Laure Tiade conceived the study, defined the study design and drafted the initial manuscript with active writing contribution of all authors. Régine Attia-Konan, Madikiny Coulibaly and 
Aïssata Dagnogo defined the data collection strategy and coordinated data collection. Jérôme Kouame, Kouame Koffi and Annita Hounsa analyzed data. Mariette Gokpeya, Simone Malik and Angèle Desquith revised critically the intellectual content. Agbaya Oga and Kouakou Luc Kouadio approved the final manuscript and revision. All authors contributed to the interpretation of the data. They agreed to be accountable for all aspects of the work.

\section{CONFLICT OF INTEREST}

The authors declare that they have no conflicts of interest in relation to this article.

\section{FUNDING AND SPONSORSHIP}

This study was self-funded.

\section{ACKNOWLEDGEMENT}

The authors would like to thank community leaders of Anonkoi-3 and participants who contributed to the study.

\section{REFERENCE}

Agence Belge de developpement (2012). Les femmes, Actrices du commerce équitable: Femmes et développement. Available at: https://www.befair.be/drupal_files/public/all-files/brochure/FEMMES_CE_FR_Web.pdf.

Allin S, Grignon M, Le Grand J (2010). Subjective unmet need and utilization of health care services in Canada: What are the equity implications?. Soc Sci Med, 70(3): 465-472. doi: 10.1016/j.socscimed.2009.10.027.

Allonier C, Dourgnon P, Rochereau T (2010). Enquête sur la santé et la protection sociale 2012,IN Institute for Research and Information in Health Economics (IRDES). Available at: https://www.irdes.fr/Publications/Rapports2010/rap180o.pdf.
Ancelot L, Bonnal L, Depret M-H (2016). Déterminants du renoncement aux soins des femmes durant leur grossesse. Rev fr écon. 31(4): 63. doi: 10.3917/rfe.164.0063.

Baggio S, Iglesias K, Fernex A (2017). Healthcare renunciation among young adults in French higher education: A population-based study. Prev Med. 99: 37-42. doi: 10.1016/j.ypmed.2017.02.002.

Bazin F, Parizot I, Chauvin P (2006). Déterminants psychosociaux du renoncement aux soins pour raisons financières dans cinq zones urbaines sensibles de la Région parisienne en 2001. Sci Soc Sante. 24(3): 11. doi: 10.3917/sss.243.0011.

Bouba-Olga O, Vigé M, Vigé B-O (2014). Healthcare renunciation: An empirical analysis from SHARE. Available at: https://hal.archives-ouvertes.fr/hal-01070962/document.

Centre International de solidarité ouvrière (2002). Le travail des femmes à l'heure de la mondialisation néolibérale. Canadian Woman Studies, 21(4): 1-12. Available at: https://www.ciso.qc.ca/wordpress/wp-content/uploads/CISO-Fiche-A4.pdf.

Chaupain-Guillot S, Guillot O, Jankeliowitch-Laval E (2014). Le renoncement aux soins médicaux et dentaires: une analyse à partir des données de l'enquête SRCV. Econ Stat, 469(1): 169197. doi: 10.3406/estat.2014.10426.

Chauvin P, Renahy E, Parizot I, Vallée J (2011). Le renoncement aux soins pour raisons financières dans l' agglomération parisienne: Déterminants sociaux et évolution entre 2005 et 2010. https://hal.archives-ouvertes.fr/inserm-00645136.

Després C, Dourgnon P, Fantin R, Jusot F (2011a). Le renoncement aux soins: 
une approche socio-anthropologique Question d'économie de la santé, Novembre (169): 1-6. Available at: http://www.irdes.fr/Publications/2011/Qes169.pdf.

Després C, Dourgnon P, Fantin R, Jusot F (2011b). Le renoncement aux soins pour raisons financières: une approche économétrique. Question d'économie de la santé, Novembre (170): 1-6. Available at: http://www.irdes.fr/Publications/2011/Qes170.pdf.

Desprès C (2013). Significations du renoncement aux soins: Une analyse anthropologique, Sci Soc Sante, 31(2): 71-96. doi: 10.1684/sss.2013.0205.

Dourgnon P, Jusot F, Fantin R (2012). Payer nuit gravement à la santé : une étude de l'impact du renoncement financier aux soins sur l'état de santé. Écon. publique, (28-29): 123-147. doi: 10.4000/economiepublique.8851.

Guessous I, Theler JM, Durosier Izart C, Stringhini S, Bodenmann P, Gaspoz JM, Wolff H (2014) . Forgoing dental care for economic reasons in Switzerland: A six-year cross-sectional population-based study. BMC Oral Health, 14(1): 1-10. doi: 10.1186/1472-683114-121.

Hartnett E, Haber J, Krainovich-Miller B, Bella A, Vasilyeva A, Lange Kessler J (2016). Oral Health in Pregnancy. J Obstet Gynecol Neonatal Nurs, 45(4), pp. 565-573. doi: 10.1016/j.jogn.2016.04.005.

Institut National de la statistique de Côte d'Ivoire (2015) . Récensement général dela population et de l'habitat 2014. Résultats globaux. Available at: http://www.ins.ci/n/templates/docss /RGPH2014D.pdf.

Jusot F (2013). Les inégalités de recours aux soins: bilan et évolution. Rev
Epidemiol Sante Publique. 61: S163S169. doi: 10.1016/j.respe.2013.05.011.

Ministère de la santé et de l'hygiène publique République de Côte d'Ivoire (2018). Rapport annuel sur la situation sanitaire (rass) 2018. Abidjan. Available at: http://dipe.info/index.$\mathrm{php} / \mathrm{fr} /$ component/jdownloads/sum mary/6-rapport-annuel-sur-la-situation-sanitaire/61-rass-2018-vf.

Revil H (2017). Femmes et hommes face au renoncement aux soins. La Santé en action. Available at: http://www.sfsp.$\mathrm{fr} /$ manifestations/manifestations/co mmunication.php?com $=1037$.

Revil H, Casagrande A, Chauveaud C (2016). Diagnostic quantitatif du renoncement aux soins des assurés de 18 Caisses Primaires d' Assurance Maladie (CPAM) Juin 2016. Grenoble. Available at: https://odenore.msh-alpes.fr/documents/analyse_diagnostic _quantitatif_-_odenore_-_vf.pdf.

Schwartz D (1995). Methodes Statistiques à l'usage des Medecins et des Biologistes, Flammarion. doi: 10.2307/2334183.

Tuckett D (2013). An introduction to medical sociology. 2013th ed, An Introduction to Medical Sociology. 2013th edn. Routledge. Tavistock Press. doi: 10.4324/9781315823843.

United Nations (2000). Rapport de la Commission de la condition de la femme constituée en comité préparatoire de la session extraordinaire de l' Assemblée générale intitulée «Les femmes en l' an 2000: égalité entre les sexes, développement et paix pour le XXIe siècle » sur. Available at: https://undocs.org/pdf?symbol=fr/A/S-23/2.

Warin P, Chauveaud C (2015). Le Baromètre du renoncement aux soins dans le GARD. Available at: https://hal.- 
Kouame et al./ Determinants of Health Care Renunciation among Women

archives-ouvertes.fr/hal-01099989.

Wolff H, Gaspoz JM, Guessous I (2011). Health care renunciation for economic reasons in Switzerland. Swiss Med Wkly. 141: 18-21. doi: 10.4414/smw.2011.13165.

World Health Organisation (2009). 10 Facts on Women's Health. Available at: https://www.who.int/gender/documents/10facts_womens_health_en.pdf?ua $=1$.

World Health Organisation (2018). La santé des femmes. Available at: https://www.who.int/fr/news-room/fact-sheets/detail/women-s-health (Accessed on 22 October 2020). 